\title{
Features of arterial hypertension course in patients with psoriasis
}

\author{
V. A. Vizir, G. I. Makurina \\ Zaporizhzhia State Medical University, Ukraine
}

Risk of cardiovascular and cerebrovascular events development in psoriasis patients is higher than in population as a whole. Combination of arterial hypertension and psoriasis is widespread and understudied state, thus the objective of our work was to reveal features of this comorbid pathology formation and course.

Material and Methods. For the implementation of the set task specific features of clinical picture of arterial hypertension (presented by essential hypertension) and psoriasis were studied. Two groups of patients included 47 persons suffering from essential hypertension and 98 persons suffering from psoriasis and essential hypertension simultaneously. Dermatosis course severity was estimated clinically using PASI index, 24-hour blood pressure index was determined by means of 24-hour blood pressure monitoring. Levels of cytokines, cortisol, and insulin were determined by immunoenzymatic methods.

Results. As the result it was revealed that patients with comorbid pathology have severe and moderate degree of arterial hypertension more often than in case of arterial hypertension without dermatosis ( $95 \%$ vs. $85 \%$ ). In this group of patients the specific feature of blood pressure circadian rhythm was revealed in form of its insufficient decrease in the evening and at night (non-dipper and night-peaker groups); total number of such patients made $63.64 \%$. Levels of cytokines (IL- $\beta$, IL-1 $\alpha$, IL-6, TNF- $\alpha$ ) in the group with comorbid pathology greatly exceed the similar indices of patients without dermatosis. This fact can be explained by available severe form of psoriasis (exudative, arthropica) with expressed systemic inflammatory reactions. Interleukins levels critically increased in patients with the 3 degree of arterial hypertension in case of combined pathology. It has been found that duration of disease especially in case of psoriasis and arterial hypertension severe form combination had negative influence on adaptive mechanisms. This fact was confirmed by considerable decreasing in cortisol level (difference made $39.74 \%$ in favor of patients with the 1-2 degree of arterial hypertension) and increasing of insulin in blood (difference made $31.91 \%$ in favor of patients with the 1-2 degree of hypertension in case of comorbid pathology).

Conclusions. Thus, psoriasis and arterial hypertension combination creates conditions for the systemic inflammatory process formation with prominent clinical manifestations of both dermatosis and hypertension, specific features of blood pressure circadian rhythm, chronic stress and decompensation formation in case of long course of disease and hypertension severe form development.

\section{Особливості перебігу артеріальної гіпертензії у хворих на псоріаз}

\section{В. А. Візір, Г. І. Макуріна}

Ризик розвитку кардіоваскулярних і цереброваскулярних подій у пацієнтів із псоріазом вищий, ніж у популяції загалом. Комбінація артеріальної гіпертензії та псоріазу є широко поширеним, але недостатньо вивченим станом.

Мета роботи - виявлення особливостей формування та перебігу цієї коморбідної патології.

Матеріали та методи. Для виконання завдання вивчали особливості клініки артеріальної гіпертензії, котра була представлена гіпертонічною хворобою, та псоріазу у двох групах пацієнтів: 47 осіб, які страждають на гіпертонічну хворобу, та 98 - на псоріаз і гіпертонічну хворобу водночас. Тяжкість перебігу дерматозу оцінювали на підставі клініки, застосовуючи індекс PASI, добовий індекс артеріального тиску визначали за допомогою добового моніторування артеріального тиску, рівні цитокінів, кортизолу, інсуліну визначали імуноферментними методами.

Результати. Виявлено, що в пацієнтів із коморбідною патологією тяжкий і середньотяжкий ступінь артеріальної гіпертензії трапляється частіше, ніж при артеріальній гіпертензії без дерматозу (95\% проти 85\%). У цій самій групі хворих виявлена особливість циркадного ритму артеріального тиску у вигляді недостатнього його зниження у вечірні й нічні години (групи non-dipper i night-peaker), загальна кількість таких пацієнтів становила 63,64\%. Рівні цитокінів (ІЛ- $\beta$, ІЛ-1 $\alpha$, ІЛ-6, ФНП- $\alpha$ ) у групі з коморбідною патологією значно перевищують аналогічні показники пацієнтів без дерматозу, що можна пояснити наявністю в них тяжких форм псоріазу (ексудативного, артропатичного) з вираженими системними запальними реакціями. Рівні інтерлейкінів критично зростають у пацієнтів із третім ступенем артеріальної гіпертензії при поєднаній патології. Виявили, що тривалість захворювання, особливо при поєднанні псоріазу з артеріальною гіпертензією, та наявність тяжкого ступеня гіпертензії негативно впливають на адаптаційні механізми, що підтверджується істотним зниженням рівня кортизолу (різниця становила 39,74\% на користь пацієнтів із 1-2 ступенями артеріальної гіпертензії) та підвищенням інсуліну у крові (різниця в 31,91\% на користь хворих із 1-2 ступенями гіпертензії при коморбідній патології).

Висновки. Отже, поєднання псоріазу та артеріальної гіпертензії створює умови для формування системного запального процесу з яскравішими клінічними проявами як дерматозу, так і гіпертензії, особливостями циркадного ритму артеріального тиску, фрормуванням картини хронічного стресу та розвитком декомпенсації під час тривалого перебігу захворювання, розвитку важкого ступеня гіпертензії.

\section{Особенности течения артериальной гипертензии у больных псориазом}

\section{В. А. Визир, Г. И. Макурина}

Риск развития кардиоваскулярных и цереброваскулярных событий у пациентов с псориазом выше, чем в популяции в целом. Комбинация артериальной гипертензии и псориаза - широко распространённое, но недостаточно изученное состояние.

Цель работы - выявление особенностей формирования и течения этой коморбидной патологии.

Key words: arterial hypertension, essential hypertension, psoriasis.

Zaporozhye medical journal 2017; 19 (2), 129-134 Dol: 10.14739/2310-1210. 2017.2.95559

E-mail: makurina.g@yandex.ua
Кмючові слова: артеріальна гіпертензія, гіпертонічна хвороба, псоріаз.

\section{Запорізький} медичний журнал. - 2017. T. 19, № 2(101). C. 129-134 
Запорожский медицинский журнал. - 2017. -

T. 19, № 2(101). C. $129-134$

Материалы и методы. Для выполнения поставленной задачи изучали особенности клиники артериальной гипертензии, представленной гипертонической болезнью, и псориаза у двух групп пациентов: 47 человек, страдающих гипертонической болезнью, и 98 - псориазом и гипертонической болезнью одновременно. Тяжесть течения дерматоза оценивали клинически, используя индекс PASI, суточный индекс артериального давления определяли с помощью суточного мониторирования артериального давления, уровни цитокинов, кортизола, инсулина определялись иммуноферментными методами.

Результаты. В результате выявлено, что у пациентов с коморбидной патологией тяжёлая и среднетяжёлая степени артериальной гипертензии встречаются чаще, чем при артериальной гипертензии без дерматоза (95\% против $85 \%$ ). В этой же группе больных выявлена особенность циркадного ритма артериального давления в виде недостаточного его снижения в вечерние и ночные часы (группы non-dipper и night-peaker), общее количество таких пациентов составило 63,64 \%. Уровни цитокинов (ИЛ- $\beta$, ИЛ-1 $\alpha$, ИЛ-6, ФНО- $\alpha$ ) в группе с коморбидной патологией значительно превышают аналогичные показатели пациентов без дерматоза, что можно объяснить наличием у них тяжёлых форм псориаза (экссудативного, артропатического) с выраженными системными воспалительными реакциями. Уровни интерлейкинов критически возрастают у пациентов с 3 степенью артериальной гипертензии при сочетанной патологии. Выявлено, что продолжительность заболевания, особенно при сочетании псориаза и артериальной гипертензии, и наличие тяжёлой степени гипертензии негативно влияют на адаптационные механизмы, что подтверждается существенным снижением уровня кортизола (разница составляла 39,74\% в пользу пациентов с 1-2 степенями артериальной гипертензии) и повышением инсулина в крови (разница в 31,91 \% в пользу больных с 1-2 степенями гипертензии при коморбидной патологии).

Выводы. Таким образом, сочетание псориаза и артериальной гипертензии создаёт условия для формирования системного воспалительного процесса с более яркими клиническими проявлениями как дерматоза, так и гипертензии, особенностями циркадного ритма артериального давления, формированием картины хронического стресса и развитием декомпенсации при длительном течении заболевания, развитии тяжёлой степени гипертензии.

According to the data of many studies patients with psoriasis (Ps) have increased risk of vascular pathology development which includes ischemic heart disease, arterial hypertension (AH) as well as metabolic syndrome, obesity and type 2 diabetes mellitus [1-3].

$\mathrm{AH}$ is widespread among patients with psoriasis and is observed almost in every third patient. Besides it has been shown that later patients with psoriasis and concomitant $\mathrm{AH}$ will have the increased risk of more severe $\mathrm{AH}$ development which will be controlled insufficiently and require more aggressive antihypertensive therapy. Even at the early stages of psoriatic process development the certain deviations in cardiovascular system activity such as tachycardia, bradycardia, dullness of heart tones, systolic murmur on the top, displacement of cardiac borders due to ventricular hypertrophy and dilatation are revealed [4-9]. It is shown that in case of psoriasis the cardiovascular disorders become apparent in form of myocardiodystrophy, myocardiofibrosis, non-rheumatic myocarditis, mitral valve defects without disorders of systemic circulation. Deviations of electric axis, signs of ciliary arrhythmia, ventricular hypertrophy and myocardial hypoxia are detected during electrocardiographic examination in some patients. Impairment of coronary circulation and decrease of myocardium contractile properties which are probably connected with lipid metabolism disorders and early development of atherosclerotic process are often registered among psoriasis patients [10]. The dependence between changes in cardiovascular system and severity of dermatosis course was detected. Cardiovascular pathology is observed by $43 \%$ more often in patients with severe forms of $\mathrm{Ps}$, in particular with psoriatic arthritis, the cerebrovascular pathology is observed by $22 \%$ more often in comparison with population in a whole [11].

Existing consensus as to comorbid conditions of psoriasis patients are recommended to be sent to specialist for early $\mathrm{AH}$ diagnostics in patients with psoriasis if the average value of two following measurements of blood pressure (BP) is as follows: systolic blood pressure (SBP) is $>140 \mathrm{~mm} \mathrm{Hg}$ and/or diastolic blood pressure (DBP) is $>90 \mathrm{~mm} \mathrm{Hg}$ [12] In spite of the fact that BP measurement in a hospital is the main diagnostic method but it is not always absolutely informative. BP measurement by means of 24 -hour blood pressure monitoring (24-hour BPM) permits to ensure assessment of BP profile within 24 hours and identify the patients who need therapeutic correction. Earlier with the help of functional diagnostic methods it has been revealed that $P$ s patients had specific features of $\mathrm{AH}$ course in form of insufficient decrease of BP level at night [13]. Previous similar studies have not been carried out among the patients with combined pathology i. e. Ps and AH. Combination of these two nosologies is not ordinary sum of two diagnoses it is specific category of patients who require individual approach to their management. Remarkable fact is that prescription of antihypertensive therapy for psoriasis patients has its own specific features. There are many observations that demonstrate Ps exacerbation due to intake of $\beta$-adrenoreceptor blockers and/or ACE inhibitors. That's why psoriasis patient management guidelines have no recommendation as to prescription of these groups of drugs. The mechanisms of their effect have not been clarified up to now but this fact is the evidence of undoubted pathogenetic connection between these two diseases.

As to the other mechanisms of psoriasis combined with arterial hypertension formation they are not studied to the full extent. There are some works which deal with issues of psoriasis formation and specific features of its course in combination with essential hypertension, but significance of hypertension and its specific features for this category of patients has not been illustrated earlier. This fact stipulates relevance of our work.

\section{Objective of the work}

To study clinical features of arterial hypertension combined with psoriasis, to determine mechanisms of this comorbid condition formation.

\section{Materials and Methods}

Complex (general clinical, laboratory and special instrument) examination of patients simultaneously suffering from psoriasis and arterial hypertension (presented only by essential 
hypertension of II degree) and being treated in department of Zaporizhzhia Regional Dermatovenerologic Clinical Dispensary of Zaporizhzhia Region Council in 2014-2016 and patients suffering from essential hypertension and being treated in department of Zaporizhzhia Municipal Hospital No. 7 was performed for achieving the target goal.

According to the study objective and tasks the examined persons were divided into the following groups:

the $1^{\text {st }}$ group $(\mathrm{EH})$ - is the patients with essential hypertension $(\mathrm{EH})-47$ persons;

the $2^{\text {nd }}$ group $(E H+P s)-$ is the patients with psoriasis and essential hypertension -98 persons.

Only patients with $\mathrm{EH}$ of the $2^{\text {nd }}$ degree were included into the research. Diagnosis was made based on Unified clinical protocol of the primary, urgent and secondary (special) medical aid "Arterial hypertension" (Order No. 384 of the Ministry of Healthcare of Ukraine of 24.05.2012) and recommendations of European society of hypertension ESH/ESC 2013 [14].

Psoriasis diagnosis was identified based on typical clinical picture of dermatosis and, if it was necessary, additional laboratory and instrumental methods of diagnostics (Unified clinical protocol of the medical aid "Psoriasis including psoriatic arthropathies", Order No. 762 of the Ministry of Healthcare of Ukraine of 20.11.2015) [15].

Prior to beginning of the study all patients were acquainted with objective, methodological features of study procedures in full scope. Informative consent application form for participation in the present study was signed by the patients personally and voluntary.

General clinical examination was carried out according to protocols for patients' with arterial hypertension and psoriasis management (Unified clinical protocol of the medical aid for cases of arterial hypertension, Order No. 384 of the Ministry of Healthcare of Ukraine of 24.05.2012 and Unified clinical protocol of the medical aid "Psoriasis including psoriatic arthropathies", Order No. 762 of the Ministry of Healthcare of Ukraine of 20.11.2015). Complaints of patients were collected, the case histories were obtained, data of objective examination (including dermatotogical examination with determination of Psoriasis Activity and Severity Index (PASI)) and data of laboratory, general clinical, biochemical, immunological and instrumental examinations were analyzed. EH patients as well as patients with combination of $\mathrm{EH}+\mathrm{Ps}$ were divided according to the arterial hypertension degree (classification ESH/ESC Guidelines for the management of arterial hypertension) under data of BP measurement in the hospital:

- the 1 degree of AH - BPs: $140-159 \mathrm{~mm} \mathrm{Hg}, \mathrm{BPd}$ : 90-99 mm Hg;

- the 2 degree of AH - BPs: $160-179 \mathrm{~mm} \mathrm{Hg}$, BPd: 100-109 mm Hg;

- the 3 degree of AH - BPs: $\geq 180 \mathrm{~mm} \mathrm{Hg}$, BPd: $\geq 110$ $\mathrm{mm} \mathrm{Hg}$.

24-hour blood pressure monitoring was made by means of ABPM-04 system (Hungary). Using this device it is possible to measure BP by oscillometric method and save BP and heart rate values during 24 hours and also to perform automatic analysis of study results and calculate derived values, generate summary protocols (in form of Tables), absolute values of graphics of BP 24-hour profile and heart rate in Medibase program. Within 24 hours during
BP monitoring and electrocardiographic examination all patients kept diaries where time of physical, emotional, mental load, any subjective changes and complaints (headache, pains or other sensations in heart area etc.), time of eating, drinking, smoking, waking up in the morning and bedtime, sleep quality, fact and time of waking up at night, time of medicines taking and their names were registered. BP registration in active period (wakeful state) (6-22 h) was made every 15 minutes and in passive period (sleeping time) (22-6 h) - every 30 minutes. After assessment of the standard indexes of 24-hour BPM and depending on the value of 24-hour index the following groups of patients were identified:

Dipper - were persons with sufficient decrease of $\mathrm{BP}$ in passive period (24-hour index made 10-20\%);

Non-dipper - were persons with insufficient decrease of BP in passive period (24-hour index made $0-10 \%$ );

Over-dipper - were persons with excessive decrease of BP in passive period (24-hour index made more than $20 \%$ );

Night-peaker - were persons with night hypertension whose BP indices in passive period were higher than in active period (24-hour index made less than $0 \%$ ).

Blood sampling for immunoenzymatic analyses was made in the morning in the fasting state between 8.00 and 9.00 a.m. from the cubital vein. Becton Dickinson Vacutainers Systems were used for blood sampling in order to perform laboratory analysis. Vials with separating gel were used for obtaining the blood serum. Blood sampling and further treatments were performed in accordance with the manufacturer's instructions. All EIA procedures were performed using the flatbed semi-automatic Digiscan SA 400 immunoenzymatic analyzer of Asys Hitech (Austria, serial No. 70384) in Central Scientific and Research Laboratory of Zaporizhzhia State Medical University.

Studied values were presented in form: selective average value \pm standard error of the average meaning. Normality of distribution was estimated under criteria of KolmogorovSmirnov (D), Lilliefors and Shapiro-Wilk (W). In case if the distribution differed from the normal one or analysis of order constants Mann-Whitney $U$ was used for two unbounded sampling for more samplings Kruskal-Wallis $\mathrm{H}$ criterion with further comparison under Games-Howell. Results of the study were processed with application of statistical package of license program Statistica ${ }^{\circledR}$ for Windows 6.0 (StatSoft Inc., No. AXXR712D833214FAN5) in Medical Informatics Department of Zaporizhzhia State Medical University and also by means of SPSS 16.0, Microsoft Excel 2010. Results are presented in form: average value \pm standard error of representation of the average value. Differences at level of significance of $<0.05$ were considered valid.

\section{Results and Discussion}

We analyzed clinical and epidemiological indices in the studied groups. Average age of patients suffering from EH made $54.3 \pm 4.7$ year; age of patients with combined pathology was equal to $52.1 \pm 4.2$ year. Ratio of men and women in both groups was statistically equivalent as well as the social status.

Psoriasis form is the sign of disease activity. Generally psoriasis vulgaris plaque type prevails in population, approximately $1 / 3$ part of patients has more severe disease 
Table 1. Distribution of patients according to level of blood pressure night decrease

\begin{tabular}{lllll}
\hline \multirow{2}{*}{ Group } & Men & \multicolumn{3}{l}{ Women } \\
\cline { 2 - 5 } & Absolute quantity, $\mathbf{n}$ & $\%$ & Absolute quantity, $\mathbf{n}$ & $\%$ \\
\hline dipper & 6 & 35.29 & 5 & 31.25 \\
non-dipper & 7 & 41.18 & 7 & 43.75 \\
over-dipper & - & - & 1 & 6.25 \\
night-peaker & 4 & 23.53 & 3 & 18.75 \\
\hline
\end{tabular}

Table 2. Values of cytokines concentration in examined persons depending on duration of $\mathrm{EH}, \mathrm{M} \pm \mathrm{m}(95 \%$-confidence interval)

\begin{tabular}{|c|c|c|c|}
\hline \multirow{2}{*}{$\begin{array}{l}\text { Indices, } \\
\text { measurement } \\
\text { units }\end{array}$} & \multicolumn{2}{|l|}{ Categories of patients } & \multirow{2}{*}{$\begin{array}{l}\text { Value of differences } \\
\text { between groups, } \Delta \%\end{array}$} \\
\hline & $\begin{array}{l}\text { EH duration } \\
\text { up to } 5 \text { years }\end{array}$ & $\begin{array}{l}\text { EH duration } \\
\text { of more than } 5 \text { years }\end{array}$ & \\
\hline \multicolumn{4}{|c|}{ Patients with EH } \\
\hline $\mathrm{IL}-1 \beta, \mathrm{pg} / \mathrm{ml}$ & $0.07 \pm 0.01(0.05-0.08)$ & $0.08 \pm 0.01(0.06-0.09)$ & $14.29 \%$ \\
\hline $\mathrm{IL}-1 \alpha, \mathrm{pg} / \mathrm{ml}$ & $0.33 \pm 0.04(0.24-0.41)$ & $0.41 \pm 0.07(0.28-0.54)$ & $24.24 \%$ \\
\hline IL-6, pg/ml & $0.79 \pm 0.15(0.6-1.18)$ & $0.89 \pm 0.14(0.62-1.17)$ & $12.66 \%$ \\
\hline TNF- $\alpha, p g / m l$ & $9.95 \pm 0.45(9.05-10.85)$ & $13.63 \pm 0.53(12.56-14.69)^{*}$ & $36.98 \%$ \\
\hline \multicolumn{4}{|c|}{ Patients suffering from EH combined with Ps } \\
\hline $\mathrm{IL}-1 \beta, \mathrm{pg} / \mathrm{ml}$ & $0.23 \pm 0.08(0.07-0.39)$ & $0.62 \pm 0.18(0.27-0.98)^{*}$ & $169.57 \%$ \\
\hline $\mathrm{IL}-1 \alpha, \mathrm{pg} / \mathrm{ml}$ & $0.97 \pm 0.06(0.88-1.12)$ & $1.9 \pm 0.53(0.83-2.96)^{\star}$ & $95.88 \%$ \\
\hline IL-6, pg/ml & $4.5 \pm 0.6(4.01-5.2)$ & $5.76 \pm 0.55(4.06-7.46)$ & $28.00 \%$ \\
\hline TNF- $\alpha, p g / m l$ & $20.45 \pm 0.84(18.77-22.12)$ & $87.6 \pm 43.69(0.22-174.98)^{*}$ & $328.36 \%$ \\
\hline
\end{tabular}

*: $p$ is $<0.05$ in comparison with group of patients with disease duration up to 5 years.

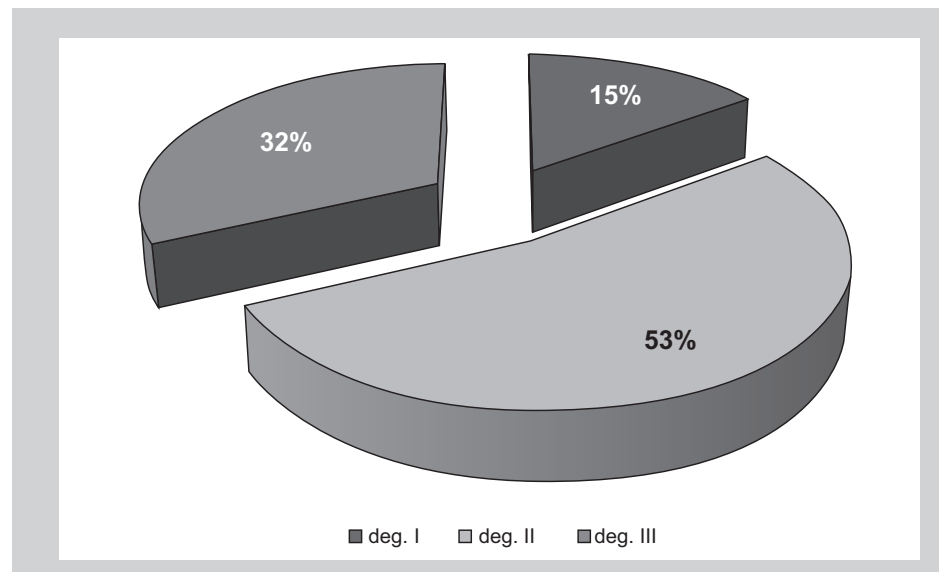

Fig. 1. Distribution of the first group patients according to arterial hypertension degree.

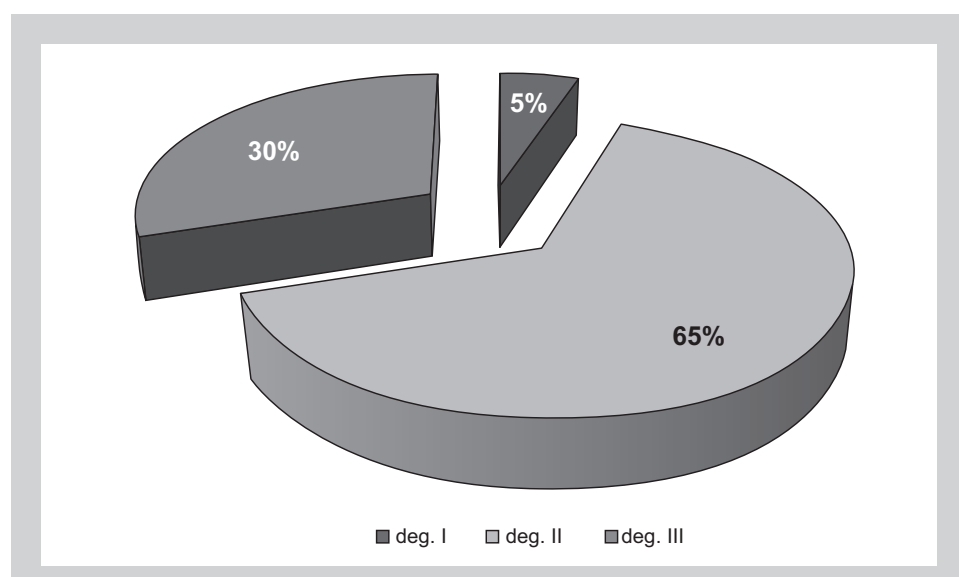

Fig. 2. Distribution of the second group patients according to arterial hypertension degree. forms. During studying of psoriasis forms another situation was revealed in patients with EH+Ps: 58 patients suffered from severe forms of psoriasis with PASI index $>30$, it made $59 \%$. Pathological process on the skin was presented by more edematous, infiltrate widespread papules, plaques on the surface of which not only typical silver and white furfures but serosanguineous crusts were identified. The disease often was persistent, therapy-resistant and recurrent. Besides the certain gender differences were observed, thus men had excudative form of psoriasis plaque type more often and women had psoriasis arthropica.

Fig. 1 and 2 show the distribution of patients of the 1 and the 2 groups according to arterial hypertension degree. The first group comprised 7 patients with the first degree of $\mathrm{AH}(15 \%), 25$ patients with the second degree of $\mathrm{AH}(53 \%)$ and 15 patients with the third degree of $\mathrm{AH}(32 \%)$. In the second group hypertension severity was more obvious because there was registered higher specific weight of patients with the 2 and the 3 degree of $\mathrm{AH}$, thus patients with the 1 degree were 5 persons ( $5 \%)$, the 2 degree $-64(65 \%)$, the 3 degree -29 persons $(30 \%)$.

In examining the level of blood pressure night decrease by method of 24-hour monitoring of $\mathrm{EH}+\mathrm{Ps}$ patients group we received the following results (Table 1).

Generally 33 patients including 17 men and 16 women had 24-hour blood pressure monitoring. According to results of this examination it was revealed that majority of patients simultaneously suffering from $\mathrm{Ps}$ and $\mathrm{EH}$ had disorder of blood pressure circadian rhythm in form of insufficient blood pressure decrease in the evening and at night (non-dipper and night-peaker groups), their total quantity made $63.64 \%$ (21 cases). Insufficient decrease of the blood pressure at night is usually accompanied with frequent target organ affections such as myocardial hypertrophy, cardiac decompensation, renal failure, retinopathy, glomerular sclerosis [16]. Obtained results motivated us to pay attention on time of antihypertensive drugs prescription for patients with psoriasis and $\mathrm{EH}$ because maintaining of $\mathrm{BP}$ normal level particularly at night is required for these patients. To this end they were proposed to intake one of antihypertensive drugs in the evening.

Dynamics of cytokines level in examined persons depending on duration of $\mathrm{EH}$ is shown in the Table 2.

According to the Table 2 data the highest values of cytokines were registered in group EH+Ps with longer AH history. Generally the inflammatory process was more obvious in the group of patients with comorbid pathology. The fact was that clinically psoriasis in these patients was not presented by ordinary and the most widespread form of dermatosis, such as psoriasis vulgaris plaque type, but more severe long-lasting form, such as exudative psoriasis, which is accompanied with high values of PASI index (32.1 2.9 in the present group), and psoriasis arthropica. Hence the high values of interlinks are absolutely unexplained in this group. In the arterial hypertension group and the combined pathology group increase in the studied indices over time indicates the importance of disease duration, need of more thorough monitoring of patients with increase of disease duration. It should be noted that among all studied interlinks the most labile one was TNF- $\alpha$ in both groups. This fact should be considered in creating of prognostic models for this category of patients. 
Values of cytokines concentration of examined persons depending on arterial hypertension degree are shown in the Table 3.

Representative and statistically important results were obtained by us while comparing values of inflammatory cytokines concentration in groups of patients with different arterial hypertension degree; the 3 degree of $\mathrm{AH}$ was always accompanied with statistical reliable and significant increase in inflammatory marker indices with considerable difference comparing to indices of similar markers of patients groups with the 1-2 degree of $\mathrm{AH}$.

Patients with $\mathrm{EH}$ of the 3 degree of $\mathrm{AH}$ demonstrated the excess of IL-1 $\beta$ indices by $414.29 \%(p<0.05), I L-1 \alpha$ by $200.00 \%(p<0.05)$, IL- 6 by $174.26 \%(p<0.05)$ and TNF- $\alpha$ by $321.62 \%(p<0.05)$ in comparison with groups of patients who suffered from essential hypertension with the 1-2 degree of $\mathrm{AH}$.

If patients had comorbid pathology of $\mathrm{EH}$ and Ps with the 3 degree of $\mathrm{AH}$, IL- $1 \beta$ exceeded the similar inflammatory marker of the 2 group persons with 1-2 degree of $\mathrm{AH}$ by $1820.00 \%(p<0.05)$, IL-1 $\alpha$ by $209.57 \%(p<0.05)$, IL- 6 by $89.95 \%(p<0.05)$ and TNF- $\alpha$ by $367.13 \%(p<0.05)$ respectively. Thus, the tendency similar to the previous comparison groups was demonstrated.

Since the majority of both patients groups the stress factor was one of the most significant causative factors which starts and maintains the disease, we have studied cortisol and insulin levels in both groups of patients. Analysis of studied indices level of the examined persons depending on EH duration is shown in Table 4.

If the patients had essential hypertension the statistically significant differences relative to the chronic stress marker such as cortisol were not revealed for patients with different duration of disease. If duration of $\mathrm{EH}$ was more than 5 years the level of cortisol in patients was higher by $2.77 \%$ in comparison with patients who suffered from $\mathrm{EH}$ within period up to 5 years. At the same time comorbid pathology promoted decrease of cortisol level in patients with disease duration of more than 5 years and difference made $17.12 \%(p<0.05)$ in favour of patients who suffered from EH and Ps within less than 5 years. It can be the evidence of organism mobilizing resources depletion in case of combined pathology and organism stress limiting systems functional decompensation with increase in disease duration comparing to the patients without combined pathology.

As regards the key marker of organism carbohydrate metabolism state such as insulin: it increased by $23.13 \%$ $(p<0.05)$ in case of longer EH comparing to patients who suffered from $\mathrm{EH}$ within period of less than 5 years. In case of available double pathology such as $\mathrm{EH}+\mathrm{Ps}$ we have not revealed statistically significant differences depending on duration of disease course and $4.68 \%$ difference in favour of patients with $\mathrm{EH}$ duration up to 5 years is not considerable. Hence disease duration in patients with combined pathology doesn't influence the insulin plasma level while EH is accompanied with increased in insulin production in case of longer disease course.

Values of insulin and cortisol concentration indices in examined persons depending on arterial hypertension degree are presented in the Table 5.

If the patients had only essential hypertension the statistically significant differences relative to the chronic stress
Table 3. Values of cytokines concentration of examined persons depending on arterial hypertension degree, $\mathrm{M} \pm \mathrm{m}$ (95\%-confidence interval)

\begin{tabular}{|c|c|c|}
\hline \multirow{2}{*}{$\begin{array}{l}\text { Indices, } \\
\text { measurement units }\end{array}$} & \multicolumn{2}{|l|}{ Categories of patients } \\
\hline & 1-2 degree of $\mathrm{AH}$ & 3 degree of $\mathrm{AH}$ \\
\hline $\mathrm{IL}-1 \beta, \mathrm{pg} / \mathrm{ml}$ & $0.07 \pm 0.01(0.06-0.09)$ & $0.36 \pm 0.08(0.19-0.53)^{*}$ \\
\hline IL-1a, pg/ml & $0.37 \pm 0.04(0.29-0.46)$ & $1.11 \pm 0.24(0.62-1.59)^{\star}$ \\
\hline IL-6, pg/ml & $1.01 \pm 0.13(0.74-1.25)$ & $2.77 \pm 0.54(1.69-3.86)^{*}$ \\
\hline TNF- $\alpha, p g / m l$ & $11.01 \pm 0.47(10.07-11.94)$ & $46.42 \pm 18.45(9.53-83.31)^{*}$ \\
\hline IL-1 $\beta, p g / m l$ & $0.05 \pm 0.01(0.02-0.09)$ & $0.96 \pm 0.17(0.22-0.89)^{*}$ \\
\hline IL-1a, pg/ml & $0.94 \pm 0.07(0.8-1.08)$ & $2.91 \pm 0.53(0.85-3.97)^{*}$ \\
\hline IL-6, pg/ml & $3.68 \pm 1.47(0.74-6.62)$ & $6.99 \pm 0.95(4.09-7.89)^{*}$ \\
\hline TNF- $\alpha, p g / m l$ & $20.87 \pm 1.58(17.71-24.03)$ & $97.49 \pm 13.7(31.5-164.89)^{*}$ \\
\hline
\end{tabular}

*: $p$ is $<0.05$ in comparison with group of patients with 1-2 degree of $A H$.

Table 4. Cortisol and insulin levels of examined persons depending on $\mathrm{EH}, \mathrm{M} \pm \mathrm{m}$ (95\%-confidence interval)

\begin{tabular}{lll}
\hline $\begin{array}{l}\text { Indices, } \\
\text { measurement units }\end{array}$ & Categories of patients & \\
\cline { 2 - 3 } & Duration of EH up to 5 years & Duration of EH of more than 5 years \\
\hline Cortisol, $\mu \mathrm{g} / \mathrm{dl}$ & $6.13 \pm 1.97(2.18-10.08)$ & $6.3 \pm 1.38(3.54-9.06)$ \\
Insulin, $\mathrm{U} / \mathrm{ml}$ & $21.75 \pm 2.11(17.52-25.97)$ & $26.78 \pm 1.99(18.8-34.76)^{*}$ \\
Cortisol, $\mu \mathrm{g} / \mathrm{dl}$ & $22.95 \pm 1.32(20.31-25.58)$ & $19.02 \pm 0.98(17.06-20.98)^{*}$ \\
Insulin, $\mathrm{U} / \mathrm{ml}$ & $8.77 \pm 0.84(7.08-10.45)$ & $8.36 \pm 1.79(4.78-11.95)$ \\
\hline
\end{tabular}

*: $p$ is $<0.05$ in comparison with group of patients with disease duration up to 5 years.

Table 5. Insulin and cortisol levels in examined persons depending on arterial hypertension degree, $\mathrm{M} \pm \mathrm{m}$ (95\%-confidence interval)

\begin{tabular}{|c|c|c|c|}
\hline \multirow{2}{*}{$\begin{array}{l}\text { Indices, } \\
\text { measurement } \\
\text { units }\end{array}$} & \multicolumn{2}{|l|}{ Categories of patients } & \multirow{2}{*}{$\begin{array}{l}\text { Value of } \\
\text { differences } \\
\text { between } \\
\text { groups, } \Delta \%\end{array}$} \\
\hline & the 1-2 degree of $\mathrm{AH}$ & the 3 degree of $\mathrm{AH}$ & \\
\hline \multicolumn{4}{|c|}{ Patients with EH } \\
\hline Cortisol, $\mu \mathrm{g} / \mathrm{dl}$ & $21.63 \pm 1.09(19.44-23.82)$ & $19.81 \pm 1.31(17.18-22.43)$ & $-8.41 \%$ \\
\hline Insulin, U/ml & $8.68 \pm 1.09(6.51-10.85)$ & $8.33 \pm 1.65(5.02-11.63)$ & $-4.03 \%$ \\
\hline \multicolumn{4}{|c|}{ Patients suffering from Ps combined with EH } \\
\hline Cortisol, $\mu \mathrm{g} / \mathrm{dl}$ & $9.36 \pm 2.36(8.64-10.08)$ & $5.64 \pm 1.31(3.03-8.25)$ & $-39.74 \%$ \\
\hline Insulin, U/ml & $34.6 \pm 16.09(2.41-6.79)$ & $23.56 \pm 3.3(16.96-30.16)$ & $-31.91 \%$ \\
\hline
\end{tabular}

*: $p$ is $<0.05$ in comparison with group of patients with the $1-2$ degree of $A H$.

marker such as cortisol have not been revealed in patients with different disease degree. In case of the 1-2 degree of $\mathrm{AH}$ cortisol level of these patients was higher by $8.41 \%$ comparing to the patients with the 3 degree of $\mathrm{AH}$. At the same time the comorbid pathology promoted considerable decrease of cortisol level in persons with the 3 degree of $\mathrm{AH}$ and difference made $39.74 \%$ in favour of patients with the 1-2 degree of $\mathrm{AH}$. This fact can be the evidence of organism mobilizing resources depletion in case of combined pathology and organism stress limiting systems functional decompensation. Thus, patients simultaneously suffering from $\mathrm{EH}$ and Ps don't have strong potential for chronic stress resistance and their behaviour as well as therapeutic correction should consider this factor.

With regard to the key marker of organism carbohydrate metabolism state such as insulin, it has been found statistically insignificant and unreliable increase by $4.03 \%$ in case of $\mathrm{AH}$ the 1-2 degree comparing to persons with the 3 degree of $\mathrm{AH}$. In case of available comorbid pathology such as $\mathrm{EH}+\mathrm{Ps}$ we have identified difference in $31.91 \%$ in favour of patients with the 1-2 degree of $\mathrm{AH}$. Consequently in patients with combined pathology arterial hypertension degree 
effects the insulin plasma level while in case of isolated form of $\mathrm{EH}$ the significant differences depending on $\mathrm{AH}$ degree have not been found. This fact draws our attention exactly to this category of patients and requires more thorough supervision over them.

\section{Conclusions}

1. Among patients with combined pathology it is registered more cases with moderate and severe degree of arterial hypertension ( $85 \%$ in group of $\mathrm{EH}$ and $95 \%$ in group of $\mathrm{EH}+\mathrm{Ps}$ ) and greater number of severe psoriasis (59\%) relative to population in a whole. This fact is consistent with the information in literature as to the parallel development of cardiovascular events and severity of psoriasis.

2. During study of blood pressure circadian rhythm it was revealed that majority of patients simultaneously suffering from $\mathrm{EH}$ and Ps had disorders in form of insufficient decrease of blood pressure in the evening and in the night (non-dipper and night-peaker groups); their total quantity made $63.64 \%$. We suppose that it is the basic reason for obligatory blood pressure control for this category of patients, twice per 24 hours, and solving the problem of the time for antihypertensive drugs prescription.

3. It has been revealed the cytokine levels indicating more intensive systemic inflammatory process. In case of combined pathology the cytokine levels in several times exceeded comparing to arterial hypertension group (from 3.88 during studying of IL-1a levels up to 6.11 of IL-6). Levels of interlinks critically increased in patients with the 3 degree of arterial hypertension in case of comorbid pathology.

4. It has been found that comorbid pathology with disease duration of more than 5 years promoted significant decrease of cortisol level in persons with the 3 degree of $\mathrm{AH}$ (difference made $39.74 \%$ in superior of patients with the 1-2 degree of $\mathrm{AH}$ ) and increase of plasma insulin (difference made $31.91 \%$ with the $1-2$ degree of $\mathrm{AH}$ patients prevalence). It can be the evidence of organism mobilizing resources depletion in case of combined pathology and organism stress limiting systems functional decompensation.

Perspectives of further scientific researches: study of endothelial dysfunction state in patients with comorbid pathology.

\section{References}

[1] Syzon, O. O., \& Stepanenko, V. I. (2014) Kontrol za rozvytkom ta perebihom suputnoi patolohii u khvorykh na artropatychnyi psoriaz [Control for development and course of concomitant pathology in patients with psoriasis arthropica]. Ukrainskyi zhurnal dermatologii, venerologii, kosmetologii, 2(53), 13-24. [in Ukrainian].

[2] Kvershi, A. A., Choy, Kh. K., Setti, A. P., \& Kurhan, G. S. (2010) Psoriaz i risk razvitiya diabeta i gipertenzii [Psoriasis and risk of diabetes and hypertension development]. Rossijskij medicinskij zhurnal, 12, 765. [in Russian].

[3] Boehncke, W. H., Boehncke, S., Tobin, A. M., \& Kirby, B. (2011) The 'psoriatic march': a concept of how severe psoriasis may drive cardiovascular. Exp. Dermatol, 20, 303-307. doi: 10.1111/j.1600-0625.2011.01261.x.

[4] Dovzhanskij, S. I., \& Uts, S. R. (1992) Psoriaz ili psoriaticheskaya bolezn'. [Psoriasis or psoriatic disease]. Saratov. [in Russian].

[5] Herédi, E., Végh, J., Pogácsás, L., Gáspár, K., Varga, J., Kincse, G. et al. (2016) Subclinical cardiovascular disease and it's improvement after long-term TNF- $\alpha$ inhibitor therapy in severe psoriatic. J Eur Acad Dermatol Venereol, 9. doi: 10.1111/jdv.13649.

[6] Horreau, C., Pouplard, C., Brenaut, E., Barnetche, T., Misery, L., Cribier, B., et al. (2013) Cardiovascular morbidity and mortality in psoriasis and psoriatic arthritis: a systematic literature review. J. Eur. Acad. Dermatol. Venerel., 3, 12-29. doi: 10.1111/jdv.12163.
[7] McDonald, I., Connolly, M., \& Tobin, A. M. (2012) Review of psoriasis, a known risk factor for cardiovascular disease and its impact on folate and homocysteine metabolism. Journal of Nutrition and Metabolism, 2012, 965385. doi: 10.1155/2012/965385

[8] Shrivastava, V. K., Londhe, N. D., Sonawane, R. S., \& Suri, J. S. (2015) Exploring the color feature power for psoriasis risk stratification and classification: A data mining paradigm. Comput Biol Med., 65, 54-68. doi: 10.1016/j.compbiomed.2015.07.021.

[9] Stern, R. (2010) Psoriasis is not usefull independent risk factor for cardiovascular disease. J.I.D, 130, 917-919. doi: 10.1038/jid.2009.446.

[10] Cyganok, S. S. (1997) Cerebrokardial'nye narusheniya i ikh korrekciya u bol'nykh psoriazom [Cerebrocardial disorders and their correction in psoriasis patients]. Vestnik dermatologii i venerologii, 2, 27-30. [in Russian].

[11] Polachek, A., Touma, Z., Anderson, M., \& Eder, L. (2017) Risk of Cardiovascular Morbidity in Patients with Psoriatic Arthritis: A Meta-Analysis of Observational Studies. Arthritis Care Res (Hoboken), 69(1), 67-74. doi: $10.1002 / a c r .22926$.

[12] Daudén, E., Castañeda, S., Suárez, C., Garcia-Campayo, J., Blasco,A. J., Aguilar, M. D., et al. (2013) Clinical practice guideline for an integrated approach to comorbidity in patients with psoriasis. JEADV, 27, 1387-1404. doi: 10.1111/jdv.12024.

[13] Ragozin, R. O. (2014) Biologicheskie ritmy arterial'nogo davleniya u bol'nykh psoriazom [Biological blood pressure rhythm in psoriasis persons]. Zdorov'e i obrazovanie v XXI veke, 12, 1-4. [in Russian].

[14] (2013) $2013 \mathrm{ESH} / \mathrm{ESC}$ Guidelines for the management of arteria hypertensionю J. Hypertens, 31(7), 1281-1357.

[15] (2016) Unifikovanyi klinichnyi protokol pervynnoi, vtorynnoi, tretynnoi medychnoi dopomohy "Psorias, vkliuchaiuchy psoriatychni artropatii". [Unified clinical protocol of the primary, secondary and tertiaty medical aid "Psoriasis including psoriatic arthropathies"]. Kyiv. [in Ukrainian].

[16] Sirenko, Yu. M. (2011) Hipertonichna khvoroba i arterialni hipertenzii. [Essential hypertension and arterial hypertensions]. Donetsk. [in Ukrainian].

\section{Information about authors:}

Vizir V. A., MD, PhD, DSci, Professor, Vice-rector for educational work, Zaporizhzhia State Medical University, Ukraine. Makurina G. I., MD, PhD, Associate Professor, Department of Dermatovenerology and Cosmetology with the Course of Dermatovenerology and Aesthetic Medicine of the Post-graduate Education Faculty, Zaporizhzhia State Medical University, Ukraine.

\section{Відомості про авторів:}

Візір В. А., А-р меА. наук, професор, проректор із навчальновиховної роботи, Запорізький державний медичний університет, Україна.

Макуріна Г. І., канА. меА. наук, Аоцент каф. дерматовенерології та косметології з курсом Аерматовенерології і естетичної медицини ФПО, Запорізький державний медичний університет, Україна.

\section{Сведения об авторах:}

Визир В. А., А-р меА. наук, профессор, проректор по учебновоспитательной работе, Запорожский государственный медицинский университет, Украина.

Макурина Г. И., канА. меА. наук, доцент

каф. Аерматовенерологии и косметологии с курсом Аерматовенерологии и эстетической меАицины ФПО, Запорожский государственный медицинский университет, Украина.

Конфмікт інтересів: віАсутній.

Conflicts of Interest: authors have no conflict of interest to declare.

Надійшло Ао редакції / Received: 14.02.2017

Після Аоопрацювання / Revised: 27.02.2017

Прийнято Ао Аруку / Accepted: 01.03.2017 